\title{
Media framing of stem cell research: a cross-national analysis of political representation of science between the UK and South Korea
}

\author{
Leo Kim
}

ABSTRACT: This paper compares opinion-leading newspapers' frames of stem cell research in the UK and South Korea from 2000 to 2008. The change of news frames, studied by semantic network analysis, in three critical periods (2000-2003/2004-2005/2006-2008) shows the media's representative strategies in privileging news topics and public sentiments. Both political and national identity represented by each media outlet play a crucial role in framing scientific issues. A news frame that objectifies medical achievements and propagates a popular hope evolves as a common discourse in The Telegraph and The Guardian, with expanded issues that both incorporate and keep in check social concerns. South Korea's Chosun Ilbo follows the frame of objectified science with a strong economic motivation, while Hankyoreh remains critical of the 'Hwang scandal' and tempers its scientific interest with broader political concerns.

\section{Context}

The aim of the study is to compare media framing of the stem cell debate in conservative and liberal newspapers in the UK (The Daily Telegraph and The Guardian) and South Korea (Chosun Ilbo and Hankyoreh). The UK and South Korea have been the most proactive and competitive countries in promoting life science, human embryonic stem cell (hESC) research in particular. Governmental promotion includes not only financial support but also active institutional establishments, including systematic efforts to develop favorable public opinion. The two countries have also competed and influenced each other in the hESC research field. In the UK, the first cloning of a sheep, Dolly, in 1997, by Sir Ian Wilmut, triggered scientific and social debates on its implication. In 2004, in South Korea, Dr. Woo-Suk Hwang claimed that he had derived a stem cell line for the first time from a cloned embryo, using the somatic cell nuclear transfer (SCNT) technique that Professor Wilmut developed.

Hwang's 'success' stirred debates across the world even before he was discredited for scientific misconducts that included unethical collection of ova and fabrication of experiments. Hwang's achievement confirmed the potential of hESC research, and the need for an expanded governmental support. However, when it was seen as a success, it heralded a fearful future of 'human cloning', and when seen as a failure, confirmed the uselessness of 'unethical' research. The repercussions of the Hwang scandal did not stop with his disgrace. The disclosure of Hwang's technical failure compelled some prominent scientists in the UK to realize that they could no longer rely on utilizing human eggs for research. Hence the scandal became a milestone in the seeking of an alternative in the UK, including a 'hybrid \& chimera' and iPS approach.

It is important to look into how public representations of scientific developments formed the environment of support or criticism based on national and poitical context, especially how the significant opinion-leading newspapers mediate the public representation. The mass media has its own story to tell about science, exerting influence on society while accommodating 'news value'. 'Science coverage in the media not only exposes cultural trends that indicate the changing position of science, but also represents the changing characteristics of society in scientific movement. Each media outlet highlights certain concepts, discussions, events, persons, etc. differently from the others. These outlets also actively respond to the media's and nation's interest while accommodating the expressions of the public readership. 
From a comparative angle, certain themes appear or disappear along the mass media. In this sense, the complex web of media narrative also reveals gaps, intended and unintended, of knowledge and ideas, which are produced while reporting scientific events. This simultaneous effect of concealing from and revealing to readers forms a core element of the operation of discourse and power. On the other hand, characteristics and strategies of mass media are affected by national identities and political constraints. They function as cultural seedbeds of media discourse that confine the willingness and scope of media representation. Therefore, salience and frames of media discourses reflect specific national and political realities.

Cross-national studies on the public opinion of science in Europe and Northen America ${ }^{2,3}$ have canvassed the general features of framing of biotechnology. But they have not explicitly addressed political heterogeneities between liberal and conservative media in each country. As I will argue, political identity of media influence framing of scientific events, at least in the context of the stem cell debate, and the way the homogeneities and heterogeneities are negotiated itself reveals interesting characteristics of national identity. New research elucidating the relation between national and political context across eventful time periods is therefore essential.

\section{Objective}

In the comparative design, the three main variables addressed are:

1) Political context (liberal \& conservative opinion-leading newspapers)

2) National context (UK \& South Korea)

3) Three time spans emerging between year 2000 to 2008

In relation to the three variables above, the study attempts to answer to the questions:

a) Which is the most important factor driving the stem cell debate in each period? - political stance (variable 1) or national identity (variable 2)?

b) What are the similarities and differences between a) the conservative and liberal newspapers and b) the countries as a whole?

c) Overall, what kind of frames and discourses emerge in driving the public opinion of science by the media?

\section{Method}

\section{Salience and framing: from network perspective}

Salience designates the coverage of news articles, which indicates the intensity of controversy and interest in scientific issues. Framing, on the other hand, refers to 'the way a story is told by unfolding arguments, using metaphors and imagery that define a problem, arriving at causal or moral attributions, and prescribing particular remedies'. A frame is the intuitive structure linking metaphors and concepts that decides the relation between essence and meaning, event and fact. The construction of frame is the process of perceiving a political and social agenda ${ }^{5}$ that emerges out of the public imagination.

In conventional methodology, measuring salience typically means, in brief, counting the number of articles on relevant issues; a frame is measured through content analysis, the clustering of indices such as main topic, controversy, evaluation, etc. ${ }^{6}$ The semantic network analysis follows the existing method for salience but offers a more microscopic and relation-oriented approach for frame. Classical content analysis pre-categorizes a certain index and counts the frequency of those categories in news coverage. Thus relational structure of a story in the media is segregated and quantified by pre-established categories. The results of analysis tell little about the frame itself as an aggregated relation of concepts or metaphors. Conversely, relational content analysis based on semantic network focuses on the associated intentions and meanings underlying the selected cluster of concepts, and the discursive strategies behind the arguments. 


\section{Data and time-span}

The data corpus comprises a systematic selection of newspaper articles published in the UK and South Korea between 1 January 2000 and 31 December 2008. For the binary comparison of political attitudes and for the study of their interactions with science reporting, newspapers were selected that represent 'conservative' and 'liberal' opinions in each country (The Daily Telegraph and The Guardian in the UK; Chosun Ilbo and Hankyoreh in South Korea, respectively). This binary comparison does not mean to define political conservatism and liberalism in different nations. Rather, it attempts in a heuristic way to explore what kind of characteristic convergence and divergence in the discourse of stem cell research emerges across different national and ideological backgrounds that each media typically represents. The newspaper articles were downloaded from media search engines in the UK (LexisNexis (www.lexisnexis.com/uk)) and South Korea (KINDS (www.kinds.or.kr)). Keyword "stem \& cell" ('줄기세포' for Korean search) were applied, and articles with irrelevant topics merely containing the words "stem" and "cell" were removed after a thorough reading. The selection resulted in the collection of 528 articles from The Guardian, 508 from The Daily Telegraph in UK, 1,065 from Chosun Ilbo and 917 from Hankyoreh in South Korea, from the year 2000 to 2008.

As Figure 1. shows, the trajectory of the news coverage on stem cell issues are marked by three major shifts of frequency, or salience, in news reports in both countries. It implies that the data can be segmented by three crucial periods, which respectively correspond to the period before and after major stem cell events, controversy and breakthroughs in the UK and Korea, during 2004-2005. The news coverage of the four newspapers in the UK and South Korea was stable until Dr. Hwang claimed to have realized the theoretical expectation of producing stem cell lines from cloned embryos in 2004. This groundbreaking news created enormous hype and heated debates on the future of stem cell technology, diverging the news trajectories of the two countries, until the results were finally disproven by the disclosures and investigations of the Hwang team's fabrication of experiments in 2006. Afterwards, along with the legislative debate and call for unhindered scientific progress, UK coverage exhibits incremental salience of stem cell news over a decade. In contrast, the news coverage in the South Korean media plateaued after a surge of reporting during the period of Hwang controversy.

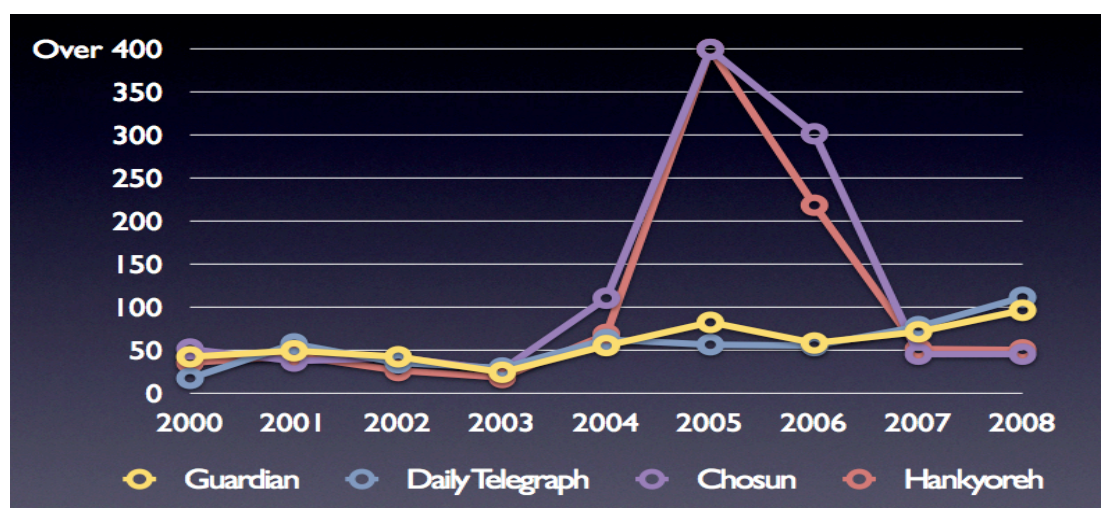

Figure 1. Intensity of news coverage on stem cell.

Newspapers and readership

\section{(a) The Daily Telegraph}

The Daily Telegraph is a daily morning newspaper distributed throughout the United Kingdom and internationally. The Telegraph has the ninth largest daily UK newspaper circulation. The Daily Telegraph has been politically conservative in modern times. According to a MORI survey conducted in $2005^{7}, 64 \%$ of Telegraph readers intended to support the Conservative Party in the coming elections. Its core readership is the traditional 'middle England', typified by retired army officers with memories of war and empire. The personal links between the paper's editors and the leadership of the Conservative Party, 
along with the paper's influence over Conservative activists, has resulted in the paper commonly being referred to, especially in Private Eye, as the 'Torygraph'.

\section{(b) The Guardian}

The Guardian had a reputation as "an organ of the middle class" in the UK. Editorial articles in The Guardian are generally to the left of the political spectrum. This is reflected in the paper's readership: a MORI poll taken between April and June $2000^{8}$ showed that $80 \%$ of Guardian readers were Labour Party voters; according to another MORI poll taken in $2005^{9}, 48 \%$ of Guardian readers were Labour voters and 34\% Liberal Democrat voters. The newspaper's reputation as a platform for liberal and left-wing opinions has led to the use of the phrase "Guardian reader" as a label for people holding such opinions.

(c) Chosun Ilbo

Chosun Ilbo has represented conservatism in modern South Korea that has been generally characterized by a support to developmental dictatorship, strong pro-Americanism, Anti-communism, and recently neo-liberal economic policy. The Chosun is the most influential newspaper media in South Korea, and had a certified average daily circulation of $1,699,430$ in $2002 .{ }^{10}$ Although it is known that the conservative status quo prefers Chosun Ilbo, the general readership of the newspaper is not as clearly delineated by class division as in the United Kingdom. It can be said that its common readership is formed by a public that shares a nostalgic sentiment about the industrializing period and rapid economic development by military leaderships (from 1960s to 1980s). Relevant science news is usually framed in relation to national glory, the personal drama of scientists, and success of industrialism.

\section{(d) Hankyoreh}

Hankyoreh newspaper was founded in 1988, a year after the political democratization of South Korea. The newspaper raised 'progress' and 'trust' as its values, based on the reflection that conventional newspapers did not carry out objective and critical reporting under the authoritarian regimes. Its size of circulation is small compared to major conservative newspapers including Chosun, ranking outside of the ten most read South Korean newspapers. But the newspaper has won first rank in media credibility from the survey conducted among professional journalists in 2009. ${ }^{11}$ Its general readership comprises a relatively young generation, progressive intellectuals and students. Hankyoreh stands for liberal and center-left positions, and expresses sympathy to new progressive issues such as environmentalism and feminism. It often raises doubts about possible side effects of new science and technology to environment and society.

\section{Data analysis}

Merging the psychological tradition's focus on textual information and the sociological concern with the construction of meaning, most contemporary views of framing focus on variations in the semantic context of information. ${ }^{12}$ In this regard, the main characteristics of the frame can be summarized in three aspects: First, frames involve selectivity, rendering some aspects of an salient issue. Second, frames give meaning by following some central organizing idea. Third, frames perform argumentative functions: they define situations, establish causal chains, provide the evaluative standards against which propositions are evaluated, and chart the options for treatment and action lying ahead. ${ }^{33}$ Insofar as the frames are represented by selective links of concepts, those words and concepts are ideological units of life which both reflect and refract particular social relations. ${ }^{14}$

There have been vigorous challenges to developing a methodology to represent this kind of discursive model as a visible map, extracted from texts, and analyze and compare these 'cognitive maps' that are networks of symbols composed of concepts and keywords. ${ }^{15}$ Semantic network analysis (SNA) is a form of content analysis which extracts the network of relations between objects as expressed in a text. Coding texts as maps focuses the user on investigating meaning among texts by finding relationships among words and themes, and by identifying central words in specified relations. The union of all statements per texts forms a semantic map of keywords that is equivalent to a network. ${ }^{16}$ 
Automap utilized for text analysis is an automatic and co-occurrence based network tool, which extracts and analyzes links among words to model the author(s)'s "mental map" as a network of links. ${ }^{17}$ By operating Automap (and visualizing tool ORA), text goes through the following stages:

a) Preprocessing stage:

a. Stemming of variable words

b. Deletion of syntactically functional words including articles, adverbs and verbs. Descriptive adjectives are also deleted, except for those denoting specified meaning such as 'therapeutic' and 'reproductive' within the text.

c. Making the list of generalization thesauri of synonyms

d. Applying a threshold that erases words that occurred less than twice each year

b) Transformation of the remaining text into an adjacency matrix of keywords (.xml file)

c) Visualization and calculation of social network indices by ORA

Table 1 shows the outcome of the automated data coding. Then the visualized semantic map has a coalition of words with hierarchically distributed linkages and locations of concepts. The result represents a power structure that privileges certain signifiers and their relations to form both explicit and implicit knowledge and meanings, as reflected in a frame.

\begin{tabular}{llllll}
\hline Period & Characteristic & Guardian & Telegraph & Hankyoreh & Chosun \\
\hline \multirow{2}{*}{$2000-2003$} & N. of articles & 161 & 142 & 126 & 160 \\
\cline { 2 - 6 } & N. of words & 102,902 & 75,019 & 133,610 & 65,664 \\
\cline { 2 - 6 } & N. of nodes & 146 & 122 & 156 & 110 \\
\hline \multirow{2}{*}{$2004-2005$} & N. of articles & 139 & 120 & 469 & 111 \\
\cline { 2 - 6 } & N. of words & 98,145 & 80,149 & 136,068 & 199,526 \\
\cline { 2 - 6 } & N. of nodes & 175 & 149 & 181 & 322 \\
\cline { 2 - 5 } & N. of articles & 228 & 246 & 80,557 & 130,885 \\
\cline { 2 - 5 } & N. of words & 97,044 & 105,248 & 154 & 103 \\
\cline { 2 - 5 } & N. of nodes & 183 & 167 & & 394 \\
\hline
\end{tabular}

Table 1. Descriptive statistics of networks.

In the context of semantic network analysis, it is important to identify central keywords and their relations with other words to explore the narrative structure and interpret social meanings. Betweenness centrality index ${ }^{18}$ has been frequently utilized in text analysis. ${ }^{19,20,21}$ In the performative communication, interaction between two nonadjacent nodes of concepts is likely to depend on another concept for reference that functions as a 'catalysis' to join metalanguages of concepts. ${ }^{22}$ This function is translated into a node with highest betweenness centrality in semantic network when the keyword lies on the paths between the trigger of information and referent, performing a mediating role as a semiological facilitator and, rhetorically, a controller of communication. In short, the media come to 'rely on' the core keywords to deliver their news frame. Bonacich power centrality, ${ }^{23}$ on the other hand, measures the influence of each concept in relation to the neighboring concepts' prestige index in addition to its own degree of centrality. It takes account of the relations to adjacent referents and their collective influences. ${ }^{24}$ That is, $^{2}$ the trajectory of a concept in terms of Bonacich power represents the change of its influence in the entire network of news frame. 


\section{Results: Framing of stem cell events}

\section{Period 1 (2000-2003): Early hopes and concerns}

The emergent social implications of embryonic stem cell research attracted the attention of British and Korean newspapers in 2000 when scientists and legislators devised and emphasized the term 'therapeutic cloning', used to combat the public concern that the new cloning and stem cell technology might lead to human 'reproductive cloning'. ${ }^{25}$ Until 2003, the major news coverage in the two countries were similarly driven by public concerns and debates on reproductive cloning, hope for new medical application, and legislative issues to regulate the research.

In the semantic network, both The Guardian and The Daily Telegraph share many central concepts: 15 words in the top 20 list overlap whereas only 8 words do so in the Korean newspapers (Table 2). Public concerns on the embryo research occupies central location of the news frame, along with the fear of cloning humans with the emerging stem cell technology. In The Daily Telegraph, the network 'reproductive cloning' and 'therapeutic cloning' compose a major cluster of social and governmental concerns (Fig. 2). This represents both the societal situation in which the image of stem cell is barely distinguishable from the popular imagination of human reproductive cloning, and the media's initiation to make a conceptual differentiation. While The Daily Telegraph pronouncedly emphasizes objective 'research' as a priority, The Guardian highlights diverse characteristics of the actor, 'researcher' and 'scientist', that also evoke cautionary images with terms like 'slippery slope', 'eugenic(s)', 'maverick', and 'cult'.

\begin{tabular}{lllll}
\hline Rank & Guardian & Telegraph & Hankyoreh & Chosun \\
\hline 1 & researcher & research & clone & Clone \\
\hline 2 & stemcell & stemcell & biotechnology & US \\
\hline 3 & cell & cell & ethic & Ban \\
\hline 4 & human & embryo & legislation & stemcell \\
\hline 5 & embryo & clone & research & Heart \\
\hline 6 & clone & human & embryo & Dolly \\
\hline 7 & scientist & scientist & life & PPL \\
\hline 8 & US & disease & UK & Dignity \\
\hline 9 & science & treatment & committee & bioethics \\
\hline 10 & government & tissue & stemcell & Republican \\
\hline 11 & treatment & baby & fetus & Clonaid \\
\hline 12 & disease & government & SCNT & committee \\
\hline 13 & hope & science & gene & Korea \\
\hline 14 & Britain & scientist & human & president \\
\hline 15 & genetic & Britain & bioethics & Ethic \\
\hline 16 & tissue & Bush & safety & UK \\
\hline 17 & baby & doctor & society & Embryo \\
\hline 18 & company & genetic & animal & Hwang \\
\hline 19 & technology & hope & religion & adult cell \\
\hline 20 & transplant & body & Dolly & Gene \\
\hline & & & $*$ Shade: Overlapping words within national boundary
\end{tabular}

Table 2. Betweenness centrality measures (2000-2003).

Similarly, the problem of human cloning is the most central concept in both newspapers in South Korea. In the liberal Hankyoreh, the term 'ethic' is associated with diverse concepts of 'society' that refers to 'feminism', 'public opinion', 'public hearing', the prospect of 'dystopia' and 'biopiracy'. In contrast, the discussion of 'ethic' in Chosun Ilbo subsumes to the drafting of bioethical law and vague mentioning about respecting human 'dignity'. Both Korean newspapers deal cautiously with the topic of stem cell technology 
while the new development and following debates appear as foreign achievements and concerns. However, this attitude changes when the development suddenly becomes a national achievement.

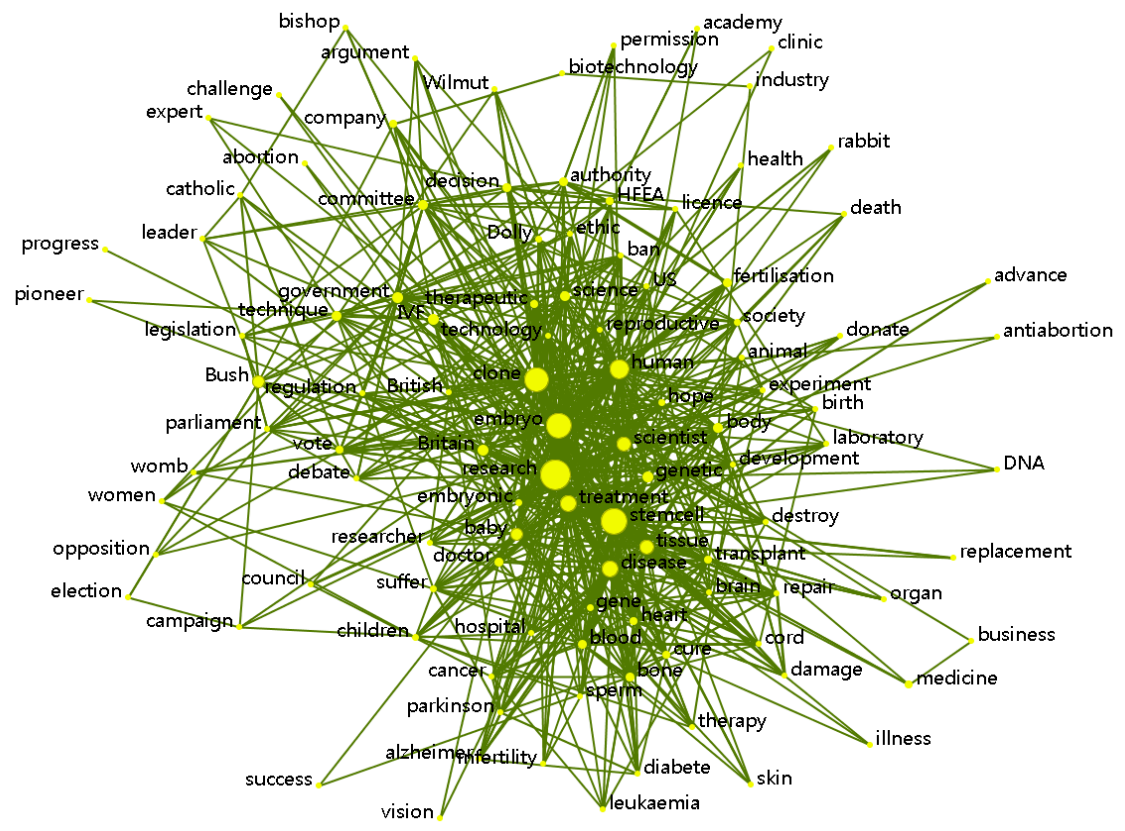

a) The Daily Telegraph

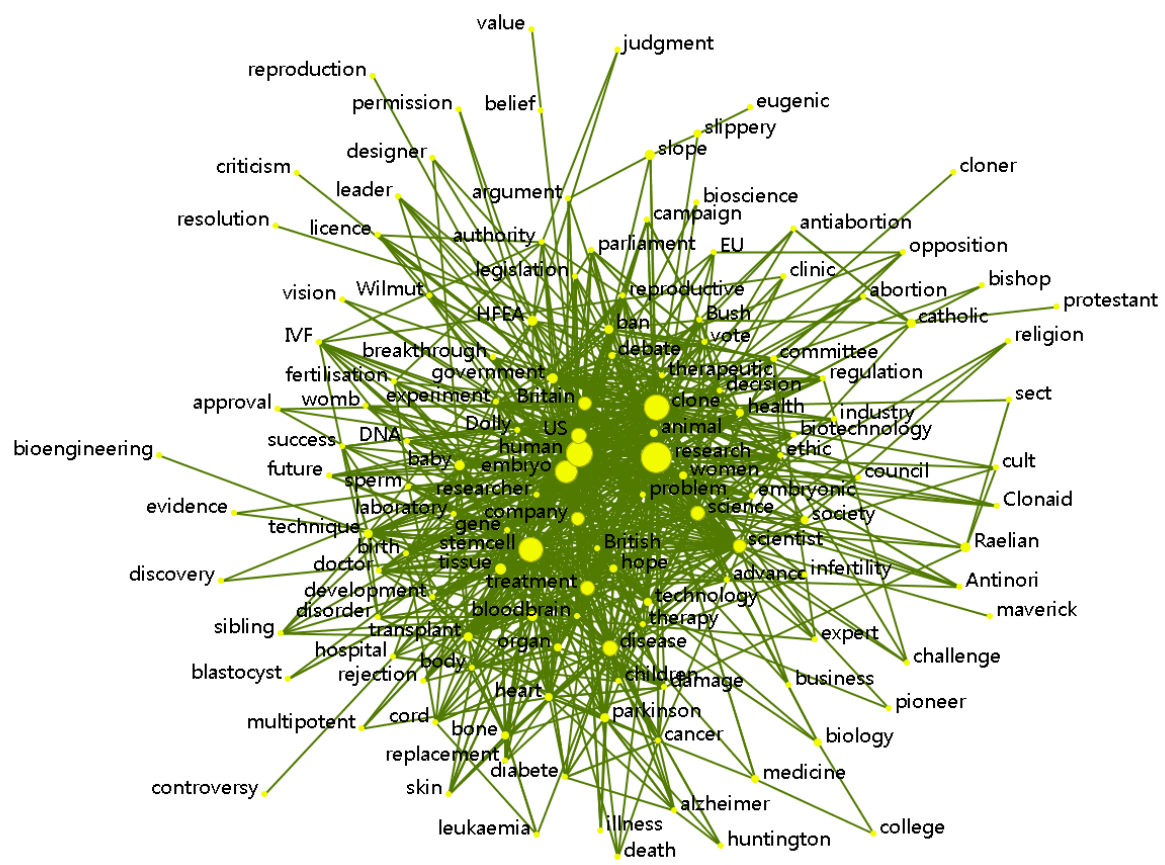

b) The Guardian

Figure 2. Networks of The Daily Telegraph and The Guardian (2000-2003). ${ }^{*}$

${ }^{*}$ Different size of nodes represent betweenness centrality. 


\section{Period 2 (2004-2005): Diverging frames}

The year 2004-2005 was an extraordinary period for stem cell science, and particularly for the Korean media. After Hwang announced a stem cell breakthrough that was considered far ahead of research centers around the world, Chosun Ilbo reported under the title "Professor Hwang's technology is subject to patenting" that assessed its economic profit would reach $\$ 300$ billion for the next 5-10 years (31 May 2005). This fantasy was soon replaced by disappointment and anguish after his scientific misconducts. Before the final confirmation of the fabrication of results in 2006, Chosun Ilbo actively supported Hwang as the builder of a 'Korea' described as the hub of BT (biotechnology) thanks to his achievements.

\begin{tabular}{|c|c|c|c|c|}
\hline Rank & Guardian & Telegraph & Hankyoreh & Chosun \\
\hline 1 & research & research & Hwang & Hwang \\
\hline 2 & stemcell & stemcell & stemcell & ova \\
\hline 3 & cell & cell & ethic & stemcell \\
\hline 4 & clone & clone & media & Korea \\
\hline 5 & scientist & embryo & Korea & ethic \\
\hline 6 & science & human & truth & US \\
\hline 7 & US & science & science & biotechnology \\
\hline 8 & human & scientist & people & $\mathrm{CEO}$ \\
\hline 9 & embryo & treatment & future & research \\
\hline 10 & disease & disease & ova & bioethics \\
\hline 11 & Britain & Britain & $\mathrm{SNU}$ & people \\
\hline 12 & treatment & hope & broadcast & committee \\
\hline 13 & hope & genetic & syndrom & controversy \\
\hline 14 & researcher & government & society & Curie Ahn \\
\hline 15 & Bush & tissue & $\mathrm{MBC}$ & $\mathrm{MBC}$ \\
\hline 16 & body & body & irrationality & government \\
\hline 17 & tissue & Catholic & frenzy & Nature \\
\hline 18 & animal & children & YTN & donation \\
\hline 19 & heart & baby & group & Sungil Roh \\
\hline 20 & therapy & blood & research & scientist \\
\hline
\end{tabular}

Table 3. Betweenness centrality measures (2004-2005).

The story of the Hwang scandal dominates the news frame of the Korean newspapers. However, Hankyoreh sharply differs from Chosun Ilbo; it frames the scientific scandal as a typical case calling for a complex reflection on the 'irrationality' of Korean society. Chosun Ilbo and Hankyoreh significantly differ in terms of utilizing central concepts, despite similarity in the scale of their news coverage in the same period (see Fig. 1). While the central concept 'ethic' in Hankyoreh explicitly denotes 'mass media' difficulties in propagating scientific achievements and of people's 'frenzied' support for Hwang regardless of his misconduct, Chosun Ilbo only vaguely refers to the narrowly defined problem of 'bioethics'. 

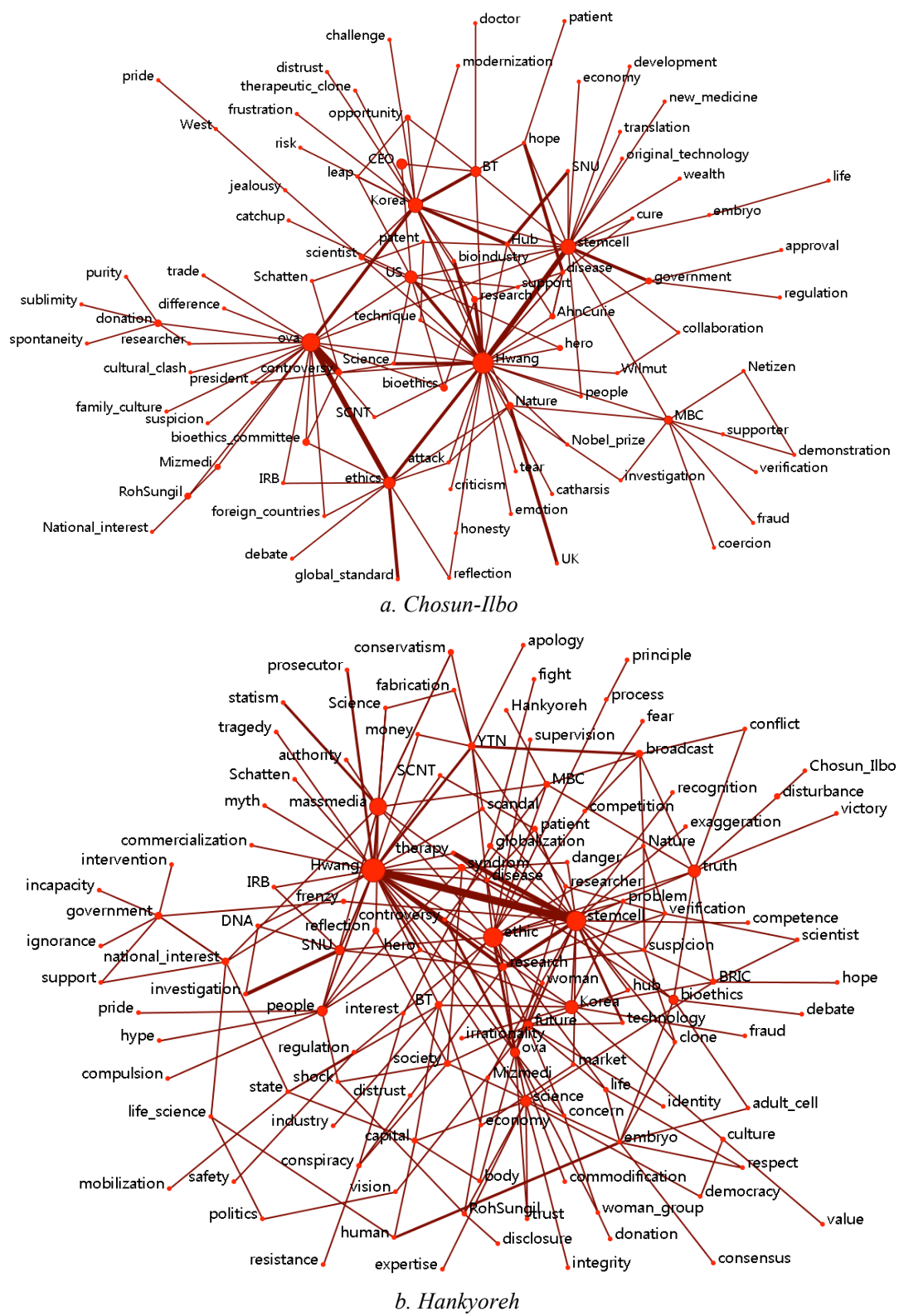

Figure 3. Extracted Networks on the Hwang controversy in Korean media (2004-2005). ${ }^{\dagger}$

Reports of the Hwang scandal in the British media often cite 'Britain', which emerges as dominant concern. Britain is related to biotechnology, company, economy, expert, government, industry, regulation, and glory. The stem cell progress made in South Korea called governmental attention to the support of domestic research through funding and legislation. In The Daily Telegraph, the overall concern arises with a question of how to solidify British leadership in the research with adequate governance, especially when faced with foreign challenges. The science editor Roger Highfield's reports titled: "Don't let others steal our glory. Britain leads the way in stem-cell research... but, if we do not act now, the benefits of our work could be lost abroad" (1 December 2004) and "UK research "tied up in red tape"” (11 March 2005), typify this approach.

\footnotetext{
${ }^{\dagger}$ Different size of nodes represent betweenness centrality.
} 
The Guardian similarly links Britain to the issue of leadership while promoting hope of new stem cell developments. In other words, it shares a 'British interest' frame with The Daily Telegraph as it reflects the growing concerns about British science that needs funding for research in face of competition from foreign scientists. While each UK newspaper maintains its distance to science and social debate, the distance has become extremely polemical in South Korea during 2004-2005 period. In the UK, it becomes visible through the network that the newspapers have come to share a common national frame incorporating the agenda of maintaining research leadership in the UK and dilluting the social concerns on reproductive cloning.

\section{Period 3 (2006-2008): Stabilizing frame}

In the UK media, the decline of 'clone' and a struggle to reposition 'hope' after the Korean debacle forms a common characteristic of frame. While the term clone has been a core signifier embodying public concern, The Daily Telegraph and The Guardian steadily lower the discursive influence of 'clone' over the periods (Fig. 4 a.). In the meantime, 'hope' is consistently utilized as a common rhetoric. With introductions of medical achievements and the delivery of emotional stories of patients' sufferings, both The Daily Telegraph and The Guardian entrench the discourse of medicalized stem cell research that is being conceptually segregated from the public image of human cloning.

\begin{tabular}{lllll}
\hline Rank & Guardian & Telegraph & Hankyoreh & Chosun \\
\hline 1 & research & research & Hwang & US \\
\hline 2 & embryo & embryo & stemcell & Obama \\
\hline 3 & scientist & stemcell & Government & stemcell \\
\hline 4 & stemcell & cell & Korea & Korea \\
\hline 5 & cell & scientist & clone & skin \\
\hline 6 & human & human & expert & success \\
\hline 7 & science & science & hybrid & science \\
\hline 8 & US & treatment & UK & organ \\
\hline 9 & researcher & disease & fabrication & disease \\
\hline 10 & disease & tissue & ethic & support \\
\hline 11 & treatment & embryonic & SNU & ACT \\
\hline 12 & government & US & prosecutor & master cell \\
\hline 13 & hope & Britain & scandal & UK \\
\hline 14 & clone & government & science & gene \\
\hline 15 & Catholic & clone & iPS & iPS \\
\hline 16 & body & hope & women & blood \\
\hline 17 & future & blood & ova & stock \\
\hline 18 & Britain & researcher & scientist & industry \\
\hline 20 & college & body & society & dog \\
\hline & tissue & & Overlapping words within national boundary \\
\hline
\end{tabular}

Table 4. Betweenness centrality measures (2006-2008). 

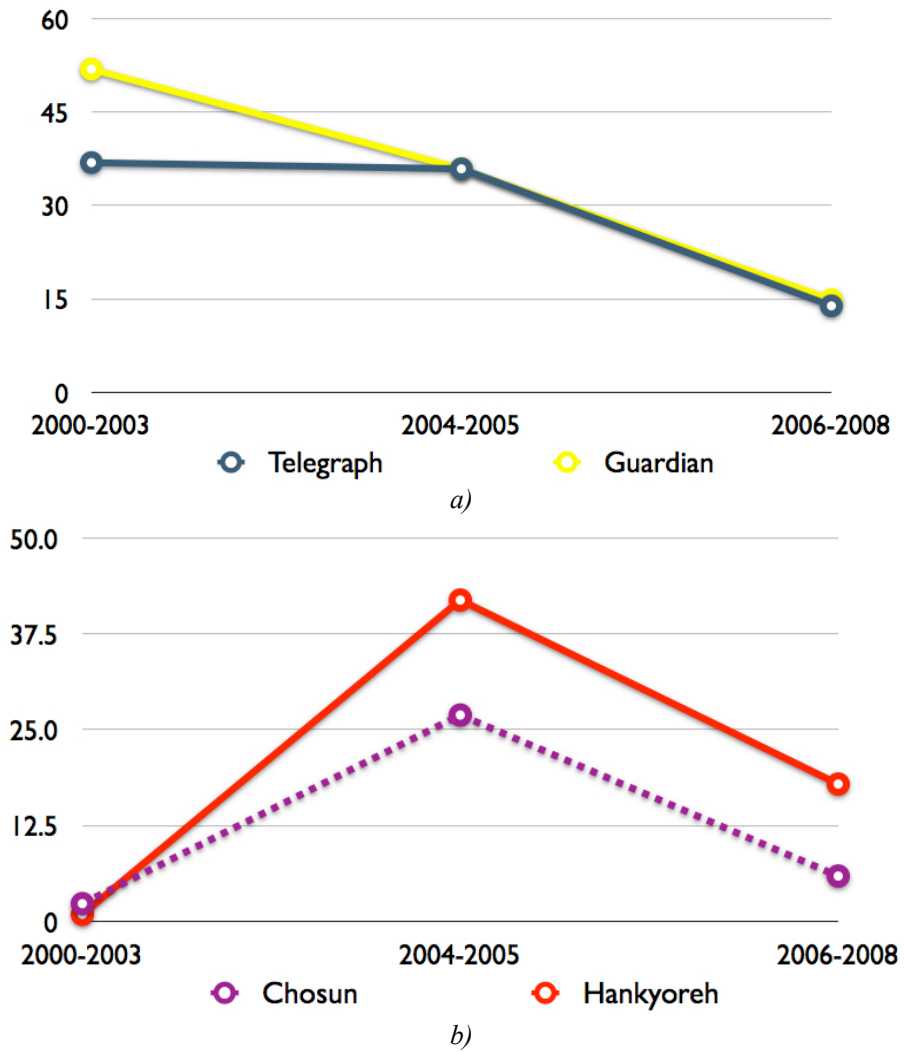

Figure 4. a. Decline of 'clone' in British media (Unit: \%). b. The rise and fall of 'Hwang' in Korean media (Unit: \%).

In comparison, South Korean newspapers face shrinkage of their discursive networks along with the rise and fall of Hwang issue (Fig. 4 b.). The Hwang debacle and prolonged media war between the liberal and conservative mass media ${ }^{26}$ attenuated the media's capacity to cover various aspects of stem cell research; whether to support Hwang or not had become a predominant subject of identity politics that has roughly drawn the line between right wing supporters of the scientific regime and left wing critics against statesponsored stem cell research. After the disclosure of Hwang's misconduct, conservative Chosun Ilbo quickly withdraws its support and barely mentions Hwang. Instead, new developments in the US and Obama's new policy to lift the ban on embryonic stem cell research are actively cited to legitimize the technology and its economic prospect. In contrast, many social problems in Korea reflected by the Hwang scandal continue to occupy the main issue frame in Hankyoreh newspaper (see Fig. 5). This ongoing reflection on the Hwang scandal is predominantly mediated by the question of better governance ('government') that now undertook the task to overcome the traumatic experience and establish a new guideline for stem cell research in South Korea. 


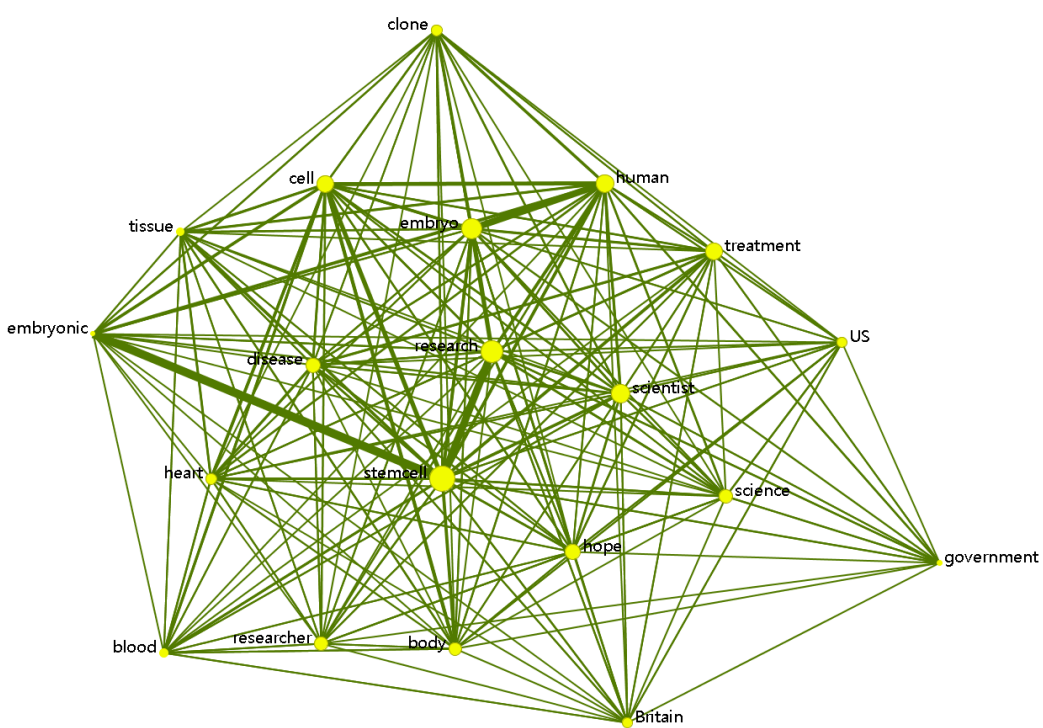

a) The Daily Telegraph

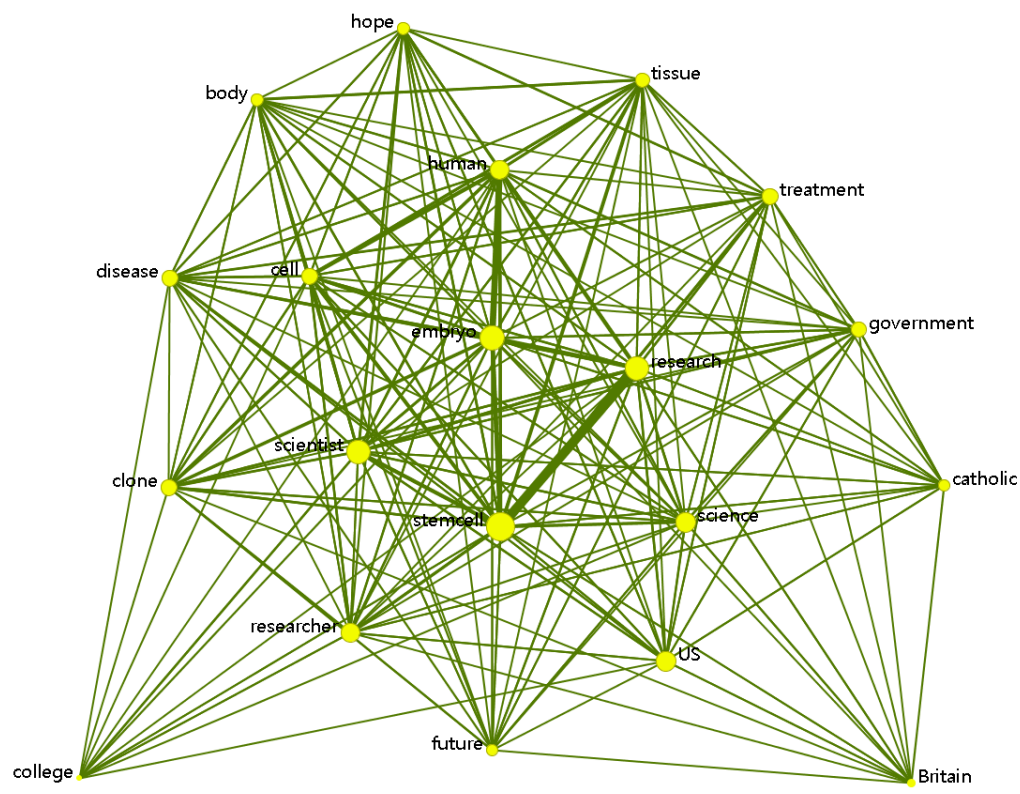

b) The Guardian 


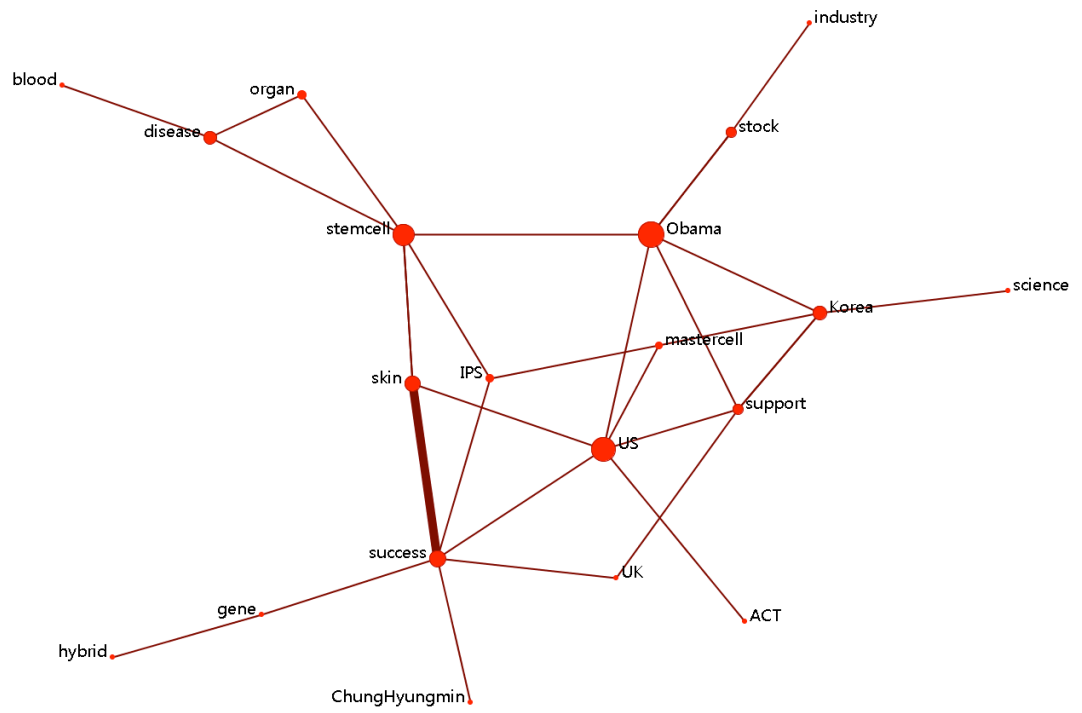

c) Chosun-Ilbo

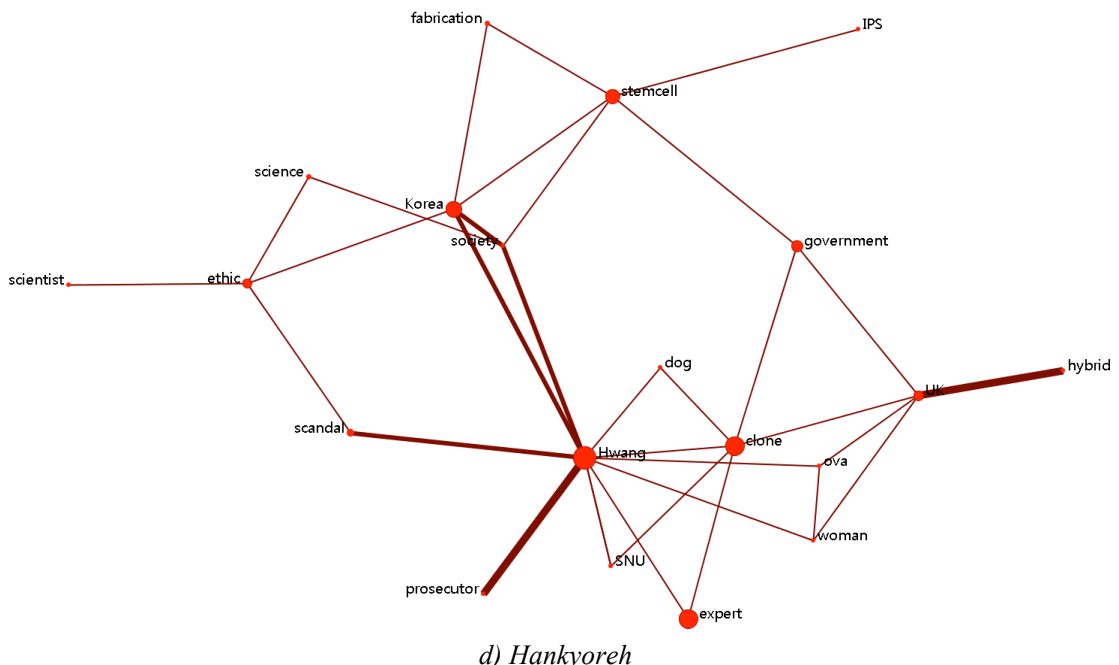

Figure 5. Extracted core concepts.

While the Hankyoreh continues to inquire about the Hwang scandal, Chosun Ilbo adopts a defensive exit strategy. Conversely, the two UK newspapers are more homogeneous in frame and become more stabilized in framing. This is observed by the networks incorporating diverse issues of scientific and social concerns, but simultaneously placing positive evaluations and objectified reports on medical progress at the core of the discursive network, which hints at a crucial cross-national difference in the media's framing strategies.

\section{Summary and discussion}

This article has showed how each newspaper has developed a unique frame by selectively linking concepts in different ways. Political and national identity of media operate as important causes of framing: while the UK media gradually rationalize stem cell research by conceptually severing its ties from the popular fear of clone, it evolves as an acute object of political struggle in South Korea (Table 5). The findings from the network structure can be substantiated by studies from other disciplines and vice 
versa. Similarly to Jenny Kitzinger ${ }^{27}$ (2008)'s qualitative media research on the same topic, the results imply that news frames more or less converge on 'rescuing hope' of stem cell research in both countries; But Hankyoreh raises more criticism of scientific governance that reflects the political culture in South Korea.

\begin{tabular}{|c|c|c|c|c|}
\hline \multirow[b]{2}{*}{ Period } & \multicolumn{2}{|c|}{ UK } & \multicolumn{2}{|c|}{ South Korea } \\
\hline & Guardian (liberal) & Telegraph (conservative) & Hankyoreh (liberal) & Chosun Ilbo (conservative) \\
\hline $\begin{array}{l}2000- \\
2003\end{array}$ & $\begin{array}{l}\text { Early concerns; Fear of } \\
\text { cloning humans with } \\
\text { emerging stem cell } \\
\text { technology. Associated } \\
\text { terms: 'eugenics', } \\
\text { 'maverick', 'cult' }\end{array}$ & $\begin{array}{l}\text { Early concerns; fear of } \\
\text { cloning with a focus on } \\
\text { social and governmental } \\
\text { concerns. } \\
\text { Key networks: 'reproductive } \\
\text { cloning' and 'therapeutic } \\
\text { cloning' } \\
\text { Early hopes; emphasis of } \\
\text { term 'hope' }\end{array}$ & $\begin{array}{l}\text { Public } \\
\text { ethics/accountability; } \\
\text { focus on ethical issues } \\
\text { related to 'society', } \\
\text { 'feminism', 'public } \\
\text { opinion', 'public } \\
\text { hearing', 'dystopia', } \\
\text { 'biopiracy' }\end{array}$ & $\begin{array}{l}\text { Bioethics; focus on the } \\
\text { drafting of bioethical laws }\end{array}$ \\
\hline $\begin{array}{l}2004- \\
2005\end{array}$ & $\begin{array}{l}\text { British interest; focus on } \\
\text { how to promote British } \\
\text { stem cell research }\end{array}$ & $\begin{array}{l}\text { British interest; focus on } \\
\text { scientific authority and the } \\
\text { need for funding for research }\end{array}$ & $\begin{array}{l}\text { Societal irrationality; } \\
\text { emphasis of term } \\
\text { 'ethic' in relation to } \\
\text { 'mass media' and } \\
\text { public 'frenzy' }\end{array}$ & $\begin{array}{l}\text { National success; Hwang } \\
\text { represented as a success, } \\
\text { reflecting the national } \\
\text { identity of S. Korea. }\end{array}$ \\
\hline $\begin{array}{l}2006- \\
2008\end{array}$ & $\begin{array}{l}\text { Medical progress }+ \text { hope; } \\
\text { focus on objectified reports } \\
\text { of medical progress, play } \\
\text { down the association with } \\
\text { 'clone' }\end{array}$ & $\begin{array}{l}\text { Medical progress; } \\
\text { objectifying medical framing } \\
\text { of stem cell research }\end{array}$ & $\begin{array}{l}\text { Social problems and } \\
\text { governance; focus on } \\
\text { general problems in S. } \\
\text { Korea reflected by the } \\
\text { Hwang scandal }\end{array}$ & $\begin{array}{l}\text { Legitimization; focus on } \\
\text { new developments in the } \\
\text { US to justify research into } \\
\text { stem cell technology; } \\
\text { emphasize scientific } \\
\text { authority; Avoid } \\
\text { mentioning Hwang }\end{array}$ \\
\hline
\end{tabular}

Table 5. Stem cell frames in UK and South Korean media 2000-2008.

Despite differences in political definitions of liberalism and conservatism in the UK and South Korea, an observed homogeneity and heterogeneity in framing signifies their common ground in science reporting. The marked similarity between 'conservative' media, The Daily Telegraph and Chosun Ilbo, can be found in a typical attitude of showing respect to scientific authority while containing wider reflections on its contentious social aspects. Conversely, a liberal characteristic is typically represented by Hankyoreh's stance to incorporate wider social concerns on stem cell research that cover topics related to feminism, rational communication, better governance, etc. In this regard, The Guardian is situated somewhere between the two political poles. But it also constructs its frame around 'hope' and 'medical achievements' in stem cell research.

National context influences the political representation of the media and their relations. The dissimilarity between Chosun and Hankyoreh is consistently greater than any others. Well known hostility between liberal and conservative media in South Korea is also represented by the scientific reporting. The Hwang scandal and related ethical issues were watershed events that polarized the liberal and conservative media. The UK newspapers turn out to be more consistent in constructing core frames throughout the decade. Both The Daily Telegraph and The Guardian converge on playing down the association of 'clone' with stem cell research and emphasizing British leadership in stem cell research. In this way, they adeptly keep in check social concerns with scientific authority and optimism.

With emphases on national interests, the political stance has subtly changed since 2004 . The development of frames is subject to ongoing dynamics, and these also re-define the meaning of being conservative or liberal. With new scientific and social events, media outlets accommodate their concept of political identity, based on their interests to adapt to the tastes of readership and the changing socioscientific environment. 


\section{Acknowledgements}

I am thankful to anonymous referees who provided valuable comments to improve this article both in content and the way of representation. Especially, the summarizing Table 5 was the direct suggestion made by one of the reviewers, which I incorporated with the upmost sense of gratitude.

\section{Notes and references}

1 M. Bauer and J.M. Gutteling (2002), Media coverage 1973-1996: trends and dynamics, in M. Bauer and G. Gaskell eds., Biotechnology: The Making of a Global Controversy, Cambridge University Press, Cambridge U.K.

2 J. Durant, M. Bauer and J. Gaskell (1998), Biotechnology in the Public Sphere, Science Museum, London U.K.

3 M. Bauer and J. Gaskell eds. (2001), Biotechnology, 1996-2000. Science Museum.

4 R.M. Entman (1993), Framing: Toward Clarification of a Fractured Paradigm, Journal of Communication 43: 51-58.

5 G. Lakoff and M. Johnson (1980), Metaphors we live by, University of Chicago Press, Chicago U.S.A.

6 M. Bauer and K. Petkova (2005), Long-Term Trends in the Public Representation of Science Across the 'Iron-Curtain': 1946-95, Social Studies of Science 34(1).

7 http://www.ipsos-mori.com/researchpublications/researcharchive/poll.aspx?oItemId=580\&view=wide.

8 International Socialism Spring 2003, ISBN 1-898876-97-5

9 Voting Intention by Newspaper Readership Quarter 12005 , Ipsos MORI, 21 April 2005.

${ }^{10}$ Korean ABC report (2002) (http://www.kabc.or.kr/) [written in Korean]

${ }^{11} \mathrm{http}: / /$ www.mediatoday.co.kr/news/articleView.html?idxno=82278 [written in Korean]

12 D. Tewksbury and D.A. Scheufele (2009), News framing theory and research, in J. Bryant and M.B. Oliver eds., Media effects: Advances in theory and research, Routledge, New York U.S.A.

${ }^{13}$ C. Baden (2010) Communication, Contextualization and Cognition: Patterns and Processes of Frames' Influence on People's Interpretations of the EU Constitution, $\mathrm{PhD}$ Thesis, University of Amsterdam, The Neatherland.

${ }^{14}$ N. Crossley and J.M. Roberts eds. (2004), After Habermas: New Perspectives on the Public Sphere, Blackwell, Oxford U.K.

${ }^{15}$ K. Carley and M. Palmquist (1992), Extracting, Representing, and Analyzing Mental Models, Social Forces 70(3): 601-636.

${ }^{16}$ CASOS (2007) Automap User's Guide, Carnegie Mellon University Press, Pittsburgh U.S.A. page 5-6.

${ }^{17}$ See CASOS (2007).

${ }^{18}$ C. Freeman (1979), Centrality in Networks: Conceptual Clarification, Social Networks 1:215-239.

${ }^{19}$ L. Leydesdorff and I. Hellsten (2005), Metaphors and Diaphors in Science Communication: Mapping the Case of 'Stem-Cell Research, Science Communication 27(1): 64-99.

${ }^{20}$ L. Leydesdoff and T. Schank (2008), Dynamic Animations of Journal Maps: Indicators of Structural Changes and Interdisciplinary Developments, Journal of the American Society for Informaiton Science and Technology 59(1).

${ }^{21}$ The betweenness centrality of node $\mathrm{v}$ in a network is defined as:

Across all node pairs that have a shortest path containing $\mathrm{v}$, the percentage that pass through $\mathrm{v}$.

The formular is:

let $S=\left\{(\mathrm{u}, \mathrm{w}) \in \mathrm{VxV} / d_{G}(\mathrm{u}, \mathrm{w})=d_{G}(\mathrm{u}, \mathrm{v})+d_{G}(\mathrm{v}, \mathrm{w})\right\}$

let between $=$

$$
\sum_{(\mathrm{u}, \mathrm{w}) \in S}\left(n_{G}(\mathrm{u}, \mathrm{v}) * \mathrm{n}_{G}(\mathrm{v}, \mathrm{w})\right) / \mathrm{n}_{G}(\mathrm{u}, \mathrm{w})
$$

Then Betweenness Centrality of node $\mathrm{v}=$ between $/((\mathrm{n}-1)(\mathrm{n}-2) / 2)$.

${ }^{22}$ R. Barthes (1967), Elements of Semiology, trans. A. Laver and C. Smith, Jonathan Cape Ltd, New York U.S.A.

${ }^{23}$ P. Bonacich (1987), Power and Centrality: A family of measures, The American Journal of Sociology 92(1): 1170-1182.

${ }^{24}$ The formaula is:

Let $\mathrm{A}=$ adjacency representation of the network $\mathrm{N}$. Then Bonacich Power Centrality for the network is the solution $\mathrm{c}$ to the following system of linear equations: $(I-? \mathrm{~A}) c=\mathrm{Ae}$

${ }^{25}$ see S. Jasanoff (2005), Designs on Nature: Science and Democracy in Europe and the United States, New York, Princeton University Press.

${ }^{26}$ Y. Won et al. (2006), Fall of Myth, Phantom of National Interest, [in Korean] Seoul: Hannarae.

${ }^{27}$ J. Kitzinger (2008), Questioning Hype, Rescuing Hope?: the Hwang Stem Cell Scandal and the Reassertion of Hopeful Horizons, Science as Culture 17(4).

\section{Author}

Leo Kim is a PhD Candidate at the LSE. His research interests lie at the interaction of actors, strategies, narratives, and knowledges concerning scientific practices. Leo is currently conducting comparative research on the governance of stem cell research between the UK and South Korea for his PhD thesis. E-mail: leo.kim.praxis@gmail.com. 
HOW TO CITE: L. Kim, Media framing of stem cell research: a cross-national analysis of political representation of science between the UK and South Korea, Jcom 10(03) (2011) A02. 